\title{
Effects of the Wire Feeding Speed on the Mechanical Properties and Electrochemical Corrosion Behaviors of a Hybrid Laser- MAG Welded X90 Pipeline Steel
}

\author{
Mei Yang ${ }^{1, *}$, Jingxiang $\mathrm{Lu}^{1}$, Yang $\mathrm{Li}^{2}$, Jian Tan ${ }^{3}$, Wenhao Zhang ${ }^{1}$, Honglang Yang ${ }^{1}$ \\ ${ }^{1}$ School of New Energy and Materials, Southwest Petroleum University, Cheng'du 610500, China \\ ${ }^{2}$ Sichuan petroleum Enginering Construction Co. Ltd, Cheng'du 610000, China \\ ${ }^{3}$ Engineering Technology Research Institute, Petro China Southwest Oil and Gas Field Company, \\ Deyang618300, China \\ *E-mail: 380056676@qq.com
}

doi: $10.20964 / 2020.10 .61$

Received: 18 June 2020 / Accepted: 9 August 2020 / Published: 31 August 2020

\begin{abstract}
This paper studies the welding of X90 pipeline steel with ER100S-G welding wire via laser-metal active gas arc (laser-MAG) hybrid welding and explores the effects of three wire feeding speeds $(8.5 \mathrm{~mm} / \mathrm{s}, 9$ $\mathrm{mm} / \mathrm{s}$, and $9.5 \mathrm{~mm} / \mathrm{s}$ ) on the microstructure, mechanical properties and corrosion resistance of the weld joints. The results demonstrate that the microstructure of the weld is composed mainly of acicular ferrite (AF) and massive ferrite (MF). The structure of the heat-affected zone (HAZ) is composed mainly of granular bainite (GB) and acicular ferrite (AF). As the wire feeding speed is increased, the weld and HAZ grains grow significantly, while the ultimate tensile strength and microhardness decrease. Polarization curves were obtained and electrochemical impedance spectroscopy (EIS) was conducted on welds and base metals. The base material has the highest corrosion resistance, and the corrosion resistance of the welds decreased as the grains grew.
\end{abstract}

Keywords: Hybrid laser-MAG welding; Mechanical properties; X90; Electrochemical experiments;

\section{FULL TEXT}

(C) 2020 The Authors. Published by ESG (www.electrochemsci.org). This article is an open access article distributed under the terms and conditions of the Creative Commons Attribution license (http://creativecommons.org/licenses/by/4.0/). 